\title{
TRADUÇÃO
}

\section{SOBRE A ELOQUÊNCIA ${ }^{1}$}

Jean-Jacques Rousseau

\author{
Tradução de Evaldo Becker
}

Perguntais por que em certas épocas a eloquência mergulha na corrupção, e como acontece de os espíritos mergulharem no mau gosto... por que, por exemplo, as figuras ousadas e exageradas por vezes agradam - e que em outros tempos nós amamos os discursos bruscos e ambíguos que deixam mais por entender do que explicitamente dizem... por que viram-se tempos em que não se tinha vergonha alguma em cometer-se injustiças.

Tal foi a vida de um homem, tais foram seus discursos.

Da mesma maneira que as ações de cada um pintam-se em seus discursos, também acontece às vezes que o gosto oratório se relacione com os gostos presentes.

Se a disciplina de um Estado se agita e degenera em delícias, é um motivo para crer que a eloquência logo adquirirá este gosto mole e efeminado; ... O espírito não pode ser pintado de forma diferente do coração.

Quando o espírito se acostuma a menosprezar as coisas usuais, e a encará-las como se fossem baixas e vis, ele também adquire o gosto pela novidade no discurso.

E não é um defeito tão grande assim empregar-se num discurso palavras pueris ou triviais, ${ }^{2 * *}$ e mais livres do que a modéstia permite, quanto se servir de um estilo muito florido e excessivamente doce, se além disso ele não significar nada e não puder produzir nenhum efeito além do próprio som das palavras.

\footnotetext{
1 A presente tradução foi realizada com base no texto contido no Volume II das obras completas de Rousseau. Euvres complètes. Tome II. Bibliothèque de la Pléiade: 1964, p. 1241.

${ }^{2}$ No corpo do texto exposto na Pléiade podemos ler Pueriles ou mauvaises. Entretanto, existem duas variantes possíveis expostas na página 1933. São elas: Pueriles et triviales e mal adaptées. Na tradução para o português achamos por bem utilizar a primeira variante.
} 